\title{
The New Role of 'Host Countries' Played by Traditional Countries of Emigration: The Experience of Italy
}

\begin{abstract}
The objective of this article is to argue that in order to successfully address the issue of integration of migrants, both voluntary and involuntary, countries need to abandon concepts of nationstate and nationalism and embrace policies of multiculturalism and active citizenship. The article specifically deals with new immigrant-receiving countries and provides the example of Italy where new policies have been adopted to deal with the integration of newcomers. Despite these efforts, hurdles are still present in the Italian immigration system. Nonetheless, it must be acknowledged that the approach espoused by Italy towards immigration is positive in that it favours integration without total assimilation. The Italian approach reflects the multiculturalism policy framework adopted by Canada, which in the opinion of this author is still the most successful policy model in addressing issues of integration and diversity.
\end{abstract}

\section{Résumé}

Lebutdecetarticleestdeproposerquesiles états veulent pouvoirgéreravecsuccèsla question de l'intégration d'immigrants, volontaires etnon-volontaires, ils doivent abandonnerlesconceptsd'étatnationetde nationalisme et adopter résolument des politiques de multiculturalisme et de citoyennetéactive. L'article traitespécifiquementducasdenouveauxpaysd'accueil des immigrants, et fournitl'exemple de l'Italie où de nouvelles politiques ontété adoptéespours'occuperdel'intégrationde nouveauxarrivés. En dépit decesefforts, il reste encore desobstacles danslesystème

Grazia ScoppioispursuingaPh.D. degreewitha specialization in Comparative International Development Education at the Ontario Institute for Studies in Education of the University of Toronto. Thetopic ofherdoctoral thesis is "Acomparative analysis of integration policies and programs for immigrants and refugees in Canada and in Italy".

\section{Grazia Scoppio}

italien d'immigration. Ondoitcependant reconnaître quel'approche adoptée par l'Italie vis-à-vis de la question de l'immigration est positive en ce qu'elle favorisel'intégration sanstoutefois aller jusqu'àl'assimilation totale. L'approche italienne reflète la politique-cadre multiculturelleadoptéeparleCanada, quireste toujours, selon l'auteur, le modèle de politique ayant le plus de succès pour s'adresserauxquestionsd'intégrationetde diversité.

\section{Introduction}

Over the last years, migration has become a global issue. In fact, there are several trends that can be detected worldwide. We are witnessing increasing global movements, favoured by faster communications, due to greater work mobility, rising poverty, ethnic conflicts, political upheavals, persecutions and wars. Population movements are not just from developing countries of the south toward developed countries of the north. On the contrary, World Bank data show that $85 \%$ of the world's population is in developing countries and uses just over of one fifth of the world's wealth/resources (quoted in Caritas, 1999). Thus, the 'gap' between north and south is widening. Most developed countries are also experiencing a demographic decline due to lower birth rates. Northern countries have responded in two different and contradictory ways to these global trends. On the one hand, many developed countries are adopting active immigration policies to recruit the human capital necessary for the survival of their nation. At the same time, some of these countries such as Northern and Western European states - also known as 'Fortress Europe'-, are enforcing tough measures in the hope of controlling migration flows and detecting 'illegal' immigrants, 'bogus' refugees, human smuggling, terrorists and crimi- nals. Southern European countries, such as Italy, are also experiencing increasing migration although not at the same levels as the rest of the European Union. Another differencelies in the fact that the Italian response to immigration has not been as harsh as some other member states of the EU. Historically a country of great emigration, Italy finds itself for the first time playing the role of the host nation and having to address issues of settlement and integration of newcomers.

In this article, Imaintain that in order to properly address the issues of migration and integration there is a need to abandon the concept of nation state and embrace a view of a multicultural state, as adopted by Canada. I also attempt to define the dimension of immigration in Italy, describe the way the government is responding, and identify some of the issues that still need to be addressed, as well as some of the barriers to integration that still need to be removed. I conclude that Italy's approach is positive, in that its public policies acknowledge the need for greater integration and for a multicultural and intercultural vision. Nonetheless, I argue that in order for immigration policies to achieve true integration, Italy and all EU states have to envision a more inclusive concept of citizenship.

\section{Framework}

\section{Migration}

According to the International Organization of Migration, there are $130 \mathrm{mil}$ lion people on the move today, of which 21.5 million are refugees and internally displaced people that concern the United Nations High Commissioner for Refugees (UNHCR) (quoted by Van Kessel, G. , 2000). There are several 'push' factors forcing these populations out of their home countries. Some of these factors are economic, i.e. hunger, poverty, unemployment and economichardshipingeneral. Someare 
human and political, i.e. violation of human rights, ethnic and political oppression, persecution and war. Some are environmental, i.e. degradation of the environment and natural disasters such as earthquakes, droughts and floods. Often times these factors are correlated. In fact, poverty and economic uncertainty can foster climates of political instability that may lead to conflicts and repression. At the same time, conflicts and wars lead to poverty, hunger and degradation of the environment. Post-war and post-conflict situations often find countries unable to cope with reconstructing cities and piecing together the economy. The main 'pull' factors that attract both voluntary and involuntary migrants towards developed countries of the north are economic opportunity, political and social stability and family reunification (for an overview of root causes of migration see International Organization for Migration and InterWorks, 1995). Through legal or illegal means, every year, millions of people from southern countries seek a better life or refuge in countries of the north.

\section{Nationalism vs. Multiculturalism}

In view of the fact that greater migration results in increasingly diverse populations, countries need to abandon the concept of 'nation' as traditionally linked to common language, ethnicity, culture, religion and historical background. Hobsbawm (1990) writes that very few nations fit into this narrow definition, since the populations of most nation-states are too heterogeneous. The concepts of 'nation' and 'nationalism' previously defined are exclusion-ary in nature and historically have led to conflicts as we witnessed in Sri Lanka, Northern Ireland, Albania and the former Yugoslavia, just to cite a few examples.

Smolicz (1998) differentiates between the concept of nation and that of state. He defines a nation as a "collectivity with a range of cultural values that are perceived as reflective of its past and an influence on both its present existence and future development" (p.61). The state, on the other hand, is a political and legal entity managing the resources of a country including issues of citizenship and political governance. According to this theory, the bond between the nation and the state is not essential for the nation to continue to exist, and the existing nation-states cannot claim, aside from a few exceptions, that there is a perfect fit between the nation and the state. That is to say, that only in a few cases, such as Japan, Iceland, Korea and Portugal, do the borders of an ethno-national group closely coincide with the borders of the state (Connor, W. 1994, p.375, quoted in Somlicz, J. 1998).

If trying to assimilate people from different ethno-cultural backgrounds into one mandated 'model' of national identity can lead to conflict, how can host countries successfully achieve 'unity within diversity'? The concept of 'national identity' should be changed to 'civicidentity' within a framework of shared values in a multicultural vision. Advocates of multiculturalism such as Banks (1997), believe that the way to achieve a balance between concepts of 'national unity' and 'ethnic diversity', is to mix and blend citizenship and multicultural education.

\section{Canada: Immigration, Citizenship and Multiculturalism}

The Canadian model of state is that of a nation of settlers and immigrants, and the population is made up of people of different cultures, races, languages, and religions. Canada has a long history as an immigrant receiving country and a long tradition of immigration policies and programs. Immigrants and refugees have played a crucial role in building our nation.

Since the Second World War, Canada has accepted close to 7.8 million immigrants or almost 150,000 annually. Since 1990 our annual intake has been just under 230,000 or about $0.7 \%$ of our population. At this rate, Canada accepts more immigrants and refugees than any other country (Van Kessel, G.C.J., 1998, p.1).

Canada is one of the few countries in the world with an active program for permanent immigration. The approach to- wards immigrants and refugees is that "in selecting immigrants and refugees we are selecting future Canadian citizens" (Van Kessel, G.C.J., 1998, p.2).

Throughout the $20^{\text {th }}$ century the Canadian immigration system and regulations have been revised and improved. In 1965, new immigration regulations were designed to eliminate all discrimination based on race, religion and national origin. The point system for immigration selection was introduced to evaluate, in a non-discriminatory way, independent immigrants on the basis of their ability to contribute to the Canadian economy. Currently, the Canadian immigration system is based on the 1976 Immigration Act and Regulation, which determined the following:

-The principles of Canadian immigration policy;

-Thegovernment's responsibility to plan future immigration fluxes;

-The distinction between refugees and immigrants;

-Canada's first refugee determination system.

In 1989 the Immigration and Refugee Board was also established. (For an overview of the Canadian immigration system see Citizenship and Immigration Canada, 2000).

The 1976 Act has been reviewed and amended several times to respond to Canada's changing policy objectives. In April 2000, BillC-31 the Immigration and Refugee Protection Act was presented as a proposal to replace the current Act. The proposed Bill has several objectives. Among the objectives related to immigration, the principal ones are:

-"To permit Canada to pursue the maximum social, cultural and economic benefits of immigration;

-To enrich and strengthen the social and cultural fabric of Canadian society, while respecting the federal and bilingual character of Canada;

-To see that all families are reunited;

-To promote successful integration of permanent residents into Canada, while recognizing that integration involves mutual obligations for new immigrants and Canadian society" (The 
House of Commons of Canada, 6 April 2000,p.2).

With respect to refugees, the Bill makes specific reference to international conventions and proposes several objectives to recognize Canada's commitment and legal obligations to provide assistance to those in need of protection and resettlement(The House of Commons of Canada, 6 April 2000, p.3).

The social outlook towards immigrants and refugees in Canada was, in the past, one of amalgamation within main-stream society but, more recently, policies have moved toward a focus on integration while acknowledging diversity (see Burnaby, B. et al., 2000). The multiculturalism policy within a bilingual framework was established at the federal level in 1971 and for three decades this multicultural vision has been clearly reflected by active immigration policies and by the creation of programs aimed at the settlement and integration of immigrants and refugees. The Government of Canada has reinforced these concepts through the 1988 Canadian Multiculturalism Act, thereby declaring that the policy of Canada is:

-To recognize that multiculturalism is a fundamental characteristic of Canadian heritage and identity;

-Topromote participation and equal treatment of individuals of all origins;

- To foster the recognition of diverse cultures of Canadian society;

-To preserve the use of other languages while strengthening the official languages of Canada;

-To ensure that all Canadians have an equal opportunity to obtain employment;

-To promote policies and programs that enhance the understanding of and respect for the diversity of the members of Canadian society (Minister of Public Works and Government Services Canada, 1999).

Canada has an open citizenship policy: that anyone born in Canada is automatically a Canadian citizen, and a Canadian resident who is $\mathbf{1 8}$ years of age and older has the right to apply for citizenship after three years of living legally and permanently in Canada. In order to become a citizen, there are some criteria to be met, such as knowledge of either English or French, and there are some exceptions that apply to people who have committed a crime and so on. Revisions to the 1977 Citizenship Act have been presented under BillC-16 the Citizenship of Canada Act. The proposed legislation establishes clear, fair and objective criteria for Canadian citizenship, ensures that future Canadians have a link to Canada, and provides measures to protect the integrity of Canadian citizenship (Citizenship and Immigration Canada, 25 Nov. 1999).

The Canadian model of the multicultural state contrasts with the traditional Italian model of nation, which was mono-cultural, mono-religious, and mono-linguistic. In Italy, migrants have been, until recently, regarded only as temporary foreign workers, often illegally employed, who were separate and distinct from mainstream society.

\section{The Dimension of Migration in Italy Overview}

Historically, Italy has been a great exporter of what in recent times has been referred to as 'manpower' or 'human resources', and is now labeled 'human capital'. These great waves of emigration ended around the mid-70s when the country's economy gained stability. Today, Italy finds itself on the 'receiving end' of migration movements, whereby increasing numbers of legal and illegal immigrants, political refugees and nomadic populations have settled in its territory.

According to the latest report on immigration published by Caritas (1999) the major Italian volunteer organization, in 1998 there were $1,250,214 \mathrm{immi}$ grants in Italy including 1,009 stateless persons. The four main continental regions of origin are Eastern Europe, North Africa, the European Union(EU) and East Asia. These figures refer only to migrants that have been 'registered' as temporary residents/workers and do not include the thousands of illegal immigrants crossing Italian borders every month. In 1998, in the region of Puglia alone, police forces detected 39,065 "clandestini" [clandestine or illegal migrants] mainly from Albania and in the same year the Department of Public Security 'expelled' 47,861 illegal immigrants (pp. 94 -97).

\section{Challenges: Immigrants and Nomads}

Many newcomers are working at jobs that Italians are no longer willing to perform, such as agriculture, assembly lines of factories, or house cleaning. Some are working illegally as 'lavoro nero' [literally: black market work]. There are also several thousands nomads living in 'nomad camps', under poor health and social conditions. The phenomenon of migration has reached considerable proportions especially in large urban areas. Unplanned urban growth has been traditionally a 'Third World' problem, but these recent waves of immigrants and refugees have caused similar effects in large cities of developed countries, such as Rome. This unplanned migration brings about issues of access to social services such as health and education and further enhances existing problems of shelter, unemployment and crime, as evidenced in the $1^{\text {st }}$ Report on the Integration of Immigrants in Italy (Commissione per le Politiche di Integrazione degli Immigrati, 1999).

\section{Challenges: Refugees}

Two different sets of data on refugees appear within the Caritas (1999) report. According to data of the Ministry of the Interior there were 40,592 asylum claims presented in 1998, whereas data of the "Commissione Centrale per il Riconoscimento dello Status di Rifugiato' [Central Committee for Refugee Status Recognition] show only 7,674 claims (Caritas, 1999, p.97 and p. IX). It is recognized in the Caritas report that figures from the Ministry of the Interior might not coincide with those of the Central Committee which are provisional data as a few thousands claims had not yet been included. However, no 
explanation is provided to clarify the reason for the contradiction in the figures.

In 1998, the rejection rate of refugee claims was $32.3 \%$ and the acceptance rate was $13.4 \%$, while over $45 \%$ of claims were still unprocessed (Caritas, 1999, p. IX) The acceptance rate is in line with most EU countries but definitely below Canada's which is around $50 \%$ or above. Assistance to refugee claimants is limited to 45,000 Italian Lira per day (about $\$ 35.00$ CAD) for 45 days. Although a temporary residency permit is issued, no work permit is granted to refugees awaiting their claims to be heard, a process that can take longer than a year (Caritas, 1999, p. III). Whereas in Canada claims can also be processed abroad through resettlement programs and refugees can be 'sponsored' by the government or through private sponsorship, in Italy 'documented' claims are to be made to the border police prior to crossing the Italian border (Parlamento Italiano, 1990).

\section{The 1998 Immigration Act}

Due to these growing challenges, in 1998 new legislation regulating immigration was approved by the Italian parliament, namely the "Legge n. 40: Disciplina dell'immigrazione e norme sulla condizione dello straniero" [Act no. 40: Regulations on Immigration and Norms on the Condition of Foreigners] (Parlamento Italiano, 1998). The main aim of the Act was to 'regularize' the status of non-EU citizens and stateless persons referred in the act as "stranieri" [foreigners], and 'exclude' illegal immigrants who do no meet the established criteria. The act regulates the issues of short-term residency permits, residency cards with indefinite validity, expulsions, illegal immigration, discrimination, family reunification, social assistance, social integration and access to education.

With respect to the education of 'foreigners', the new Immigration Act (Parlamento Italiano, 1998) has provided guidelines for regions and boards, but no national program has yet been implemented. Article 36 of the act deals specifically with 'instruction of foreigners' as well as 'intercultural education'. It specifies that compulsory education (elementary and middle school) applies to foreign children in the same way as it applies to Italian children and that the right to compulsory education is guaranteed by the state, regional authorities and local agencies, "also through courses of Italian as a second language" (Art.36). With regards to intercultural education, the guidelines indicate that intercultural activities are to be promoted by the school community. Through agreements with the Regions and with local authorities, elementary and middle schools are also to hold literacy, Italian as a second language and training programs to promote access for immigrant adults.

There is no specific mention of refugee issues, as refugees are generally regarded as ordinary migrants, although literature on refugees shows that the needs of a refugee are not always the same as those of an immigrant. With respect to youth refugees, for example, Kaprielian-Churchill and Churchill (1994) point out that "to the extent that refugee youngsters must cope with phenomena which other immigrant students do not face, their problems and requirements are different from those of voluntary immigrants" (p.2).

Few educational provisions for immigrants have been implemented at the national level. The most important one is to allow school registration for immigrant students regardless of the status of the parents. However, it should be mentioned that some successful local programs are in place, mostly in northern cities, such as the intercultural centres of Bologna (CDLEI) and Turin (CIDISS) (Commissione per le Politiche di Integrazione degli Immigrati, 1999). What seem to be lacking are national policies and programs targeting the issue of integration of immigrants and refugees within the societal pattern of the host country: In the school, in the work-place and in the community.

The Immigration Act also establishes provisions for the establishment of the 'Commissione per le Politiche di Integrazione' [Committee for Integra- tion Policies], with the objective to report yearly on the implementation status of integration policies for immigrants. The first such report was released in November 1999 (Commissione per le Politiche di Integrazione degli Immigrati, 1999). The most worrying findings of the report are the data on immigrant criminality: immigrants represent about $25 \%$ of adult inmates and over $50 \%$ of juvenileinmates. Other problems identified range from lack of cultural and linguistic integration, to unemployment and poor social conditions. The primary educational problem identified in the report is that immigrant children are being held back due to the lack of/inadequate knowledge of the Italian language. More recently, the media have reported that the highest rate of drop-outs is found among immigrant youth (Editorial, Il Tempo, 2000, Jan. 25; Editorial, Il Giornale, 2000, Jan 25).

\section{Citizenship}

In Italy, citizenship status is only granted under certain circumstances. It is not acquired through birth within Italian borders but through blood link (jus sanguinus), marriage (after three years), or after many years (more than 10) of permanent residency (Parlamento Italiano, 1992). This provision also causes problems of statelessness especially among the nomadic populations.

Hence, to the extent that citizenship implies active participation of the people/citizens in the life of their country and their community, immigrants and refugees in Italy still encounter institutional barriers to access civic and citizenship rights. In fact, immigrants and refugees cannot fully participate in the political life of the country as they have not yet been granted voting rights. It is worth noting, however, that there is lobbying to change current legislation on that regard.

\section{Summary and Conclusion}

Migration, both voluntary and involuntary, is a global phenomenon and is causing changes to the social patterns of many countries. In order to success- 
fully approach the issue of integration of newcomers into the host society, countries need to abandon the concepts of nation and nationalism and embrace policies of multiculturalism and active citizenship. Traditional emigration countries, such as Italy, now face a new role as immigration countries. It must be acknowledged that the approach adopted by Italy is positive in that its policies are not as harsh as other EU states and it favors integration without total assimilation. This approach reflects the multiculturalism policy framework adopted by Canada, which remains the most successful one in addressing the issue of integration of diverse populations. Despite these efforts, barriers are still present in the Italian system and they need to be addressed. The greatest challenges are to improve the refugee determination system, eliminate educational and linguistic barriers, improve social conditions, achieve equal opportunity in the workforce, and remove barriers to citizenship rights.

Critics of multiculturalism argue that gaps are still present in the Canadian system and that some newcomers 'fall between the cracks'. They may also argue that, due to these shortcomings, multiculturalism has failed in its scope. Nationalists maintain that multiculturalism results in lack of assimilation and lack of national identity.

As already stated, the response to these criticism is twofold. Firstly, the whole notion of national identity is challenged by growing migration resulting in increasingly diverse populations. Secondly, although there are still challenges in the Canadian system that definitely need to be addressed, multiculturalism has been by far more successful than assimilation policies in allowing people from different cultural, linguistic, religious and ethnic backgrounds to coexist in an atmosphere of mutual respect. As observed by the International Organization for Migration, (1995, p. 86) "The multicultural approach makes it possible for migrants to become citizens while maintaining distinct cultural differences".

Canada may be criticized for not having a strong national identity, but it has acknowledged and built upon the notion of the coexistence of diversity and the acceptance of the 'other'. Although its policies and programs may not be perfect, they deserve the attention of countries such as Italy where such policies and programs have only recently been brought to the forefront in the policy arena. So far no government has achieved the perfect social system where everyone starts the race equally and where all systemic barriers such as racism and xenophobia are removed. Nonetheless, in the past thirty years, policy-makers in Canada have made the best attempt toaccept and accommodate immigrants and refugees through active immigration policies, settlement programs, equal opportunity programs, anti-racism policies, and so forth.

Although the Italian immigration policy is based on a multicultural (and intercultural) approach, there is a fundamental difference between Italian and Canadian policy. The most significant difference is that in Canada landed immigrants and recognized refugees are not regarded as temporary foreign workers but they are considered the citizens of tomorrow. In an editorial of The Globe and Mail (March 14, 2000, p.A14), the Canadian policy of integration of immigrants is compared with the policies of several European countries and Japan where they "clearly have trouble accepting the change from an ethnic definition of nationality to a volitional one". According to The Globe and Mail those countries should make integration policies a priority, they should look at how we do things in Canada ".... A policy of exuberant integration has worked for us and, in one way or another, it can work for countries where the old blood-based definition of nation clashes daily with the future of collective prosperity."

\section{References}

Banks, J.A. (1998). An Introduction to Multicultural Education. Boston, MA; Toronto: Allyn and Bacon.

Banks, J. A. (1997). Educating Citizens in a Multicultural Society. New York: Teachers College Press.

Burnaby, B., James, C. and Regier, S. (2000, March). Working Paper Series:The Role of Education in Integrating Diversity in the
Greater Toronto Area. Toronto, On.: Joint Centre of Excellence for Research on Immigration and Settlement.

Canadian Council for Refugees. (1998). Best Settlement Practices:Settlement Services for Refugees and Immigrants in Canada. Montreal, Quebec: Canadian Council for Refugees.

Caritas di Roma. (1999). Immigrazione: Dossier Statistico '99. Roma, Italy: Edizioni Anterem.

Churchill, S. (1996). The Decline of the NationState and the Education of National Minorities. International Review of Education. Vol. 42 (4), pp. 265-290.

Citizenship and Immigration Canada. Uuly 2000) Milestones of the 20th Century Minister of Public Works and Government Services Canada. Available on-line: http:/ /www.cic.gc.ca/english/about/milestones/index.html.

Citizenship and Immigration Canada. (25 Nov. 1999) News Release: A Citizenship of Canada Act Proposed in Parliament. Available on-line: http:/www.cic.gc.ca/ english/press/99/9937-pre.html.

Citizenship and Immigration Canada. (1999). Canada...The Place to Be: Annual Immigration Plan for the year 2000. Available on line: http://www.ci.gc.ca/english/pub/ anrep00e.html [04/04/00]

Citizenship and Immigration Canada. (1998). Immigrant Services. Available on-line: http://www.cic.gc.ca/english/newcomer/ [04/04/00].

Citizenship and Immigration Canada. (1976). Immigration Act and Regulations. Available on-line: http://www.cic.gc.ca/

Commissione per le Politiche di Integrazione degli Immigrati. (30 Nov. 1999) Primo Rapporto sull'Integrazione degli Immigrazti in Italia. Roma: Presidenza del Consiglio dei Ministri. Available on-line: http://www.affarisociali.it/servizi/ rapporto1999.htm.

Connor, W. (1993). Beyond reason: The nature of the ethnonational bond. In Ethnic and Racial Studies. Vol. 16-3, pp. 373-389.

Consultorio Familiare di Azignano (1997). Il Bambino e la Famiglia nella Societa' Multietnica. Ovest Vicentino(VI):ULSS n. 5, Regione Veneto.

Editorial.(March 14, 2000). The Canadian Way to Redefine Nationality. The Globe and Mail. (p. A14).

Editorial. (25 Jan. 2000). Scuola, ogni anno tremila abbandoni. Il Tempo. Roma, Italy.

Editorial. (25 Jan. 2000). Oltre tremila ragazzi abbandonano la scuola ogni anno. Il Giornale. Milano, Italy.

Hobsbawm, E.J. (1990). Nations and Nationalism since 1780: Programme, Myth, Real- 
ity. Cambridge, UK: Cambridge University Press.

International Organization for Migration and InterWorks. (Sept. 1995). Overview of International Migration. Geneva, Switzerland: International Organization for Migration. Available on-line: http:// www.iom.int/.

Kaprielian-Churchill, I. and Churchill, S. (1994). The Pulse of the World: Refugees in Our Schools. Toronto, On.: OISE Press, The Ontario Institute for Studies in Education.

Knowles, V. (1997). Strangers at Our Gates: Canadian Immigration and Immigration Policy, 1540-1997. Toronto, Ontario: Dundurn Press.

Minister of Public Works and Government Services Canada. (1999). Canadian Multiculturalism Act. R.S. 1985, c.24. Toronto, Ontario: Federal Publications Inc.

Parlamento Italiano (1998). Legge 6 marzo 1998, n. 40: "Disciplina dell'immigrazione e norme sulla condizione dello straniero". Gazzetta Ufficiale, n. 59 del 12 marzo 1998. Roma, Italy: Istituto Poligrafico e
Zecca delloStato. Available on-line: http:/ /www.senato.it/parlam/leggi/, or http://www.stranieriinitalia.com/leggi

Parlamento Italiano. (1992). Legge 5 febbraio 1992, n. 91: "Nuove norme sulla cittadinanza". Gazetta Ufficiale, n.38 del 15 febbraio 1992 . Roma, Italy: Istituto Poligrafico e Zecca dello Stato. Available on line: http://www.senato.it/parlam/ leggi/, or http:// www.stranieriinitalia.com/leggi .

Parlamento Italiano. (1990). Legge 28 feggraio 1990, n. 39: "Rifugiati". Gazzetta Ufficiale, no. 49 del 28 febbraio 1990. Roma, Italy: Istituto Poligrafico e Zecca dello Stato. Available on line: http:// www.senato.it/parlam/leggi/, or http:/ /www.stranieriinitalia.com/leggi.

Roncati, R. and Cicchetti, G. (Eds.) (1999). Italy in Figures. Rome, Italy: Istituto Nazionale di Statistica. Available on-line: http://istat.it

Smolicz, J. J. (1998). In search of a multicultural nation: The case of Australia from an international perspective. In Richard J. Watts and Jerzy J. Smolicz (Eds).
Cultural Democracy and Ethnic Pluralism: Multicultural and Multilingual Policies in Education. Frankfurt am Main, Germany: Peter Lang.

Smolicz, J. (1997). Cultural Democracy and Ethnic Pluralism: Multicultural and Multilingual Policies. Frankfurt am Main, Germany; New York: P.Lang.

The House of Commons of Canada. (6 April 2000) Bill C-31: An Act respecting immigration to Canada and the granting of refugee protection to persons who are displaced, persecuted or in danger. The Minister of Citizenship and Immigration. Available on-line: http://www.cic.gc.ca/ english/about/policy/legrev_e.html

Van Kessel, G. (2000). 'Current Issues in Refugee Policy: Northern and Southern Perspectives'. Summer Course on Refugee Issues 2000. Centre for Refugee Studies, York University, Toronto, Ontario.

Van Kessel, G.C.J. (1998). The Canadian Immigration System. Ottawa, Ontario: Citizenship and Immigration Canada. Available on-line: http://www.cic.gc.ca/ english/refugee/kessel-e.html. $\square$

January 200 h

\section{Dear Rofuge Sul sarileos:}

I am pleased to amnounce that Refuge, Canada's joumal focused on refugee issues, will be updating and strengthening its contentand fomat:

In lanuary 2001, Refugewill becomea quarterly publication, beginning with Volume 19, No. 3 . Rofuge will be publishing longer articles, allowing authors to pursue important and complex issues in greater depth. In addition, we will continue to invite book revievs and casecomments:

Refuge hasnotraised its subseriptionntates for eight years however, due torising production costs, it is necessary for Refuge to shightly increase tho subseription rate to 860 Canadian dollars per year, within Canada, for individual subscribers, and \$7.5 Canadian dollars for institutional subseribers within Canada. Due to Migher postal rates, the price for individual subseribers fromall other countriesis 560US dollaxs, and for institutional subscribers fromall other countries, 575 US dellars.

If your subbscription expires before or on Volume $19 . \mathrm{No}$. 2 , your renewal cheque is due. Renewal cheques received before Noveraber 30,2000 will be invoiced at the old rate for the next subscription period. This means you can renew at the present rate of $\$ 50$ Canadian dollars whin Canada and $\$ 60$ US dollars outside of Canada. If you plan to renew your subscription after November 30 , the subscription cost will be at the sew rates specified above.

In the a exd year, you can oxpectinteresting and hought-provoking thomatic issues to be covered, including a thorough analysis of aew diroctions in refugee policy in an ora of globalization, and a retrospective of the $50^{\text {th }}$ Ammivarsary of the

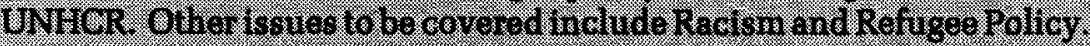

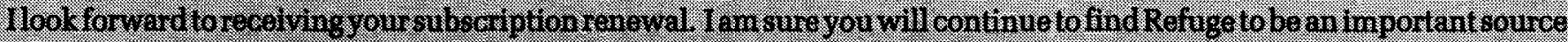
of information and critique, as vell as a construetive contribution to the on going dialogue on refugee issues.

Tours sincaroly:

(C) Grazia Scoppio, 2001. This open-access work is licensed under a Creative Commons Attribution-NonCommercial 4.0 International License, which permits use, reproduction and distribution in any medium for non-commercial purposes, provided the original author(s) are credited and the original publication in Refuge: Canada's Journal on Refugees is cited. 